\title{
Staying Relevant: How a Radio Behemoth Has Weathered the Storms of Change to Survive in the New Media Market of the $21^{\text {st }}$ Century
}

\author{
Kim L. Wangler \\ Appalachian State University \\ This paper was presented at the 2019 International Summit of the \\ Music \& Entertainment Industry Educators Association \\ March 21-23, 2019
}

https://doi.org/10.25101/19.40

\begin{abstract}
Any company that expects to survive in the $21^{\text {st }}$ century-especially in the music industry - will need to adapt to the ever-changing business landscape. Few companies have exhibited the survival instincts that iHeart Media has over their almost fifty years of existence. From exponential growth and government regulation, to name changes and rebranding, this company continues to adapt to the morphing media models of our times. Even given the recent filing for bankruptcy restructuring, iHeart Media has remained a strong force in the industry and provides an interesting historical perspective into some of the major music industry transitions of our times.
\end{abstract}

Keywords: iHeartMedia, radio, media, Live Nation, Clear Channel, music business

This paper will be published in the College Music Symposium.
Kim L. Wangler, B.M, M.M, M.B.A, joined the faculty of Appalachian State University in 2005 as the Director of the Music Industry Studies Program. Ms. Wangler teaches music management, marketing, and entrepreneurship. She has served in the industry as President of the Board of Directors for the Orchestra of Northern New York, House Manager for the Community Performance Series (serving audiences of over 1,000 people) and

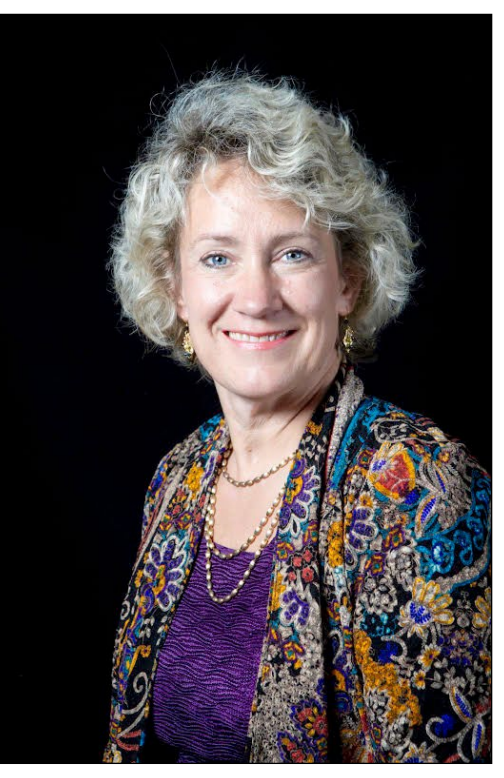
as CEO of Bel Canto Reeds - a successful on-line venture. Ms. Wangler currently works with several entrepreneurial musicians through Ars Nova Music Management and serves as Vice Chairman for the Cultural Resources Board for the town of Boone and on the Board of Directors for MEIEA. She was recently appointed to the first Music Industry Chair on the Board of Directors for the College Music Society. Ms. Wangler is published through Hal Leonard, Sage Publishing, and the MEIEA and NACWPI journals. 


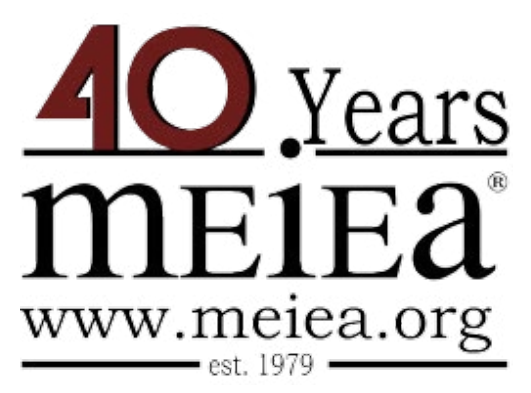

\section{PROCEEDINGS OF THE \\ 2019 INTERNATIONAL SUMMIT \\ OF THE \\ MUSIC \& ENTERTAINMENT \\ INDUSTRY EDUCATORS \\ ASSOCIATION}

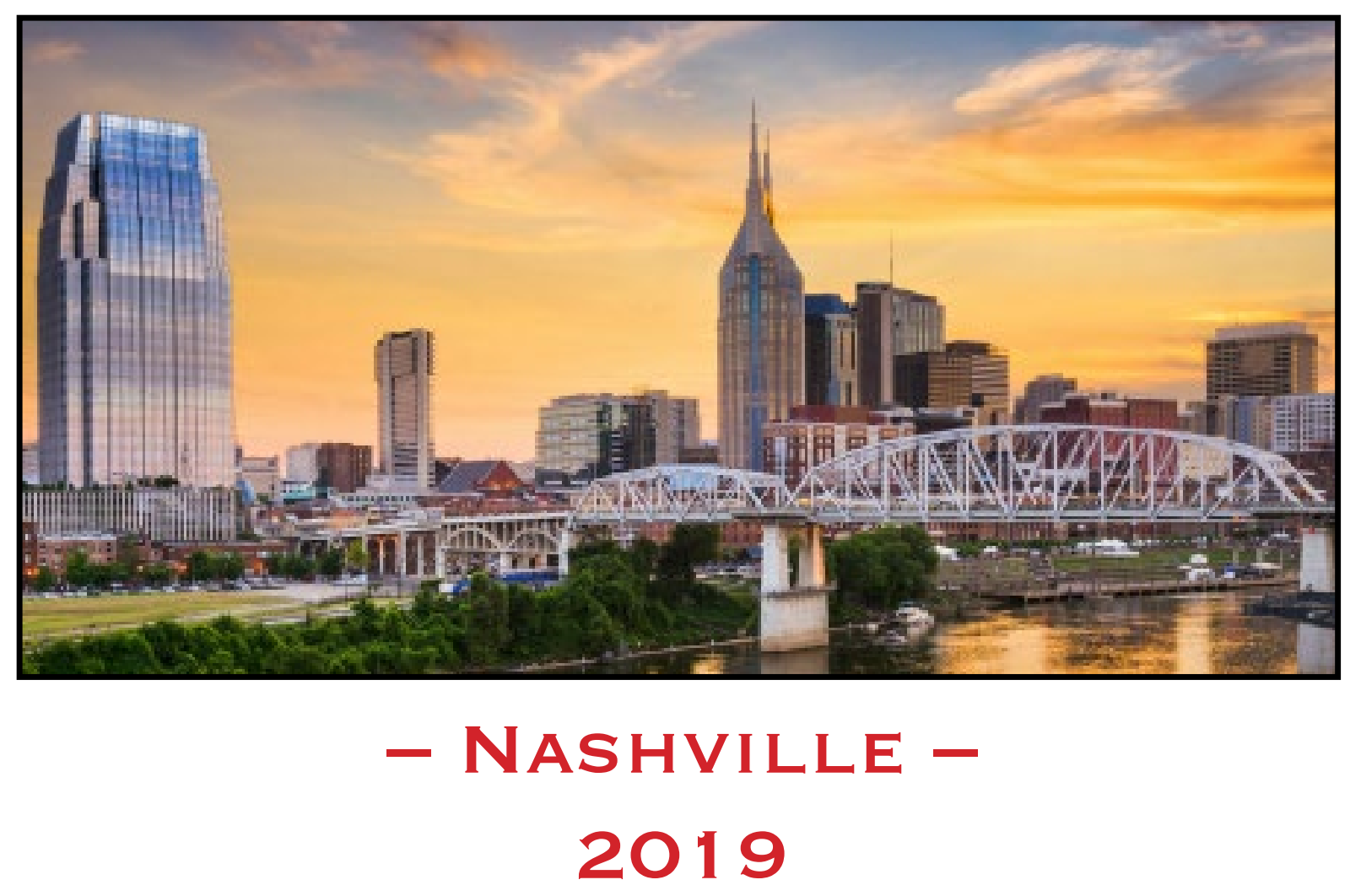

March 21 - 23, $2019 \cdot$ Belmont University - Nashville 